\title{
The effectiveness of biological and chemical systems for protecting potatoes from harmful organisms in the central zone of the Krasnodar region
}

\author{
Svetlana Nekoval", Anastasia Zakharchenko, Anastasia Sadovaya, Arina Churikova, and \\ Irina Fedoryanskaya
}

Federal State Budgetary Scientific Institution «Federal Research Center of Biological Plant Protection», Krasnodar, 39, VNIIBZR, 350039, Russia

\begin{abstract}
The biological and chemical protection system's influence on the soil mycological composition, potato plant biometric indicators, yield structural indicators, productivity, as well as the potato tuber quality has been studied. It was determined that after the biological protection system application, the genus Penicillium fungi number decreased by 4 times, the genus Aspergillus - more than 2 times, Trichoderma sp. content -2.5 times. There was an increase in the stem number in the variant with biological protection by more than 2 times, compared with the control, and by $25 \%$, compared with the chemical protection variant. The plant height in the two variants was $6.4-7.3 \%$ higher than the control values. The potato tuber total number per bush in the biological protection variant increased by $40 \%$, and the tuber mass increased by $12.4-61.7 \%$ in comparison with other variants. The yield increase was $157.3 \mathrm{c} / \mathrm{ha}$ $(50.4 \%)$ and $128.0 \mathrm{c} / \mathrm{ha}(39 \%)$ for the biological and chemical systems, respectively. The nitrate amount was within the normal range in all variants. The vitamin $\mathrm{C}$ highest content was noted in the variant with the biological protection application $(9.3 \mathrm{mg} / 100 \mathrm{~g}$ of raw substance). The starch amount varied from $20.8 \%$ to $21.3 \%$ in all variants.
\end{abstract}

\section{Introduction}

Potatoes are the third most important in the world after rice and wheat. Growing potatoes as a food source for the population is of essence in ensuring the food security of many countries. Potatoes are an important fodder crop for farm animals, and are also used as raw materials for the processing industry [1-4]. Potato tubers are known for their high nutritional properties: they include biologically valuable protein, vitamin $\mathrm{C}$ and a complex of $\mathrm{B}$ vitamins, minerals and dietary fiber [5-7]. The total area of potatoes in world agriculture is 17.5 million hectares. China ranks first in potato production (90.2 million tons). Russia ranks 4 th in terms of area (1.3 million hectares) and harvest (22.4 million tons) of this crop (according to FAOSTAT, 2018).

\footnotetext{
*Corresponding author: s.nekoval@yandex.ru
} 
Plants in general are constantly exposed to stress factors, incl. chemical pesticides, due to which their ability to resist various harmful organisms decreases [8]. Potato yield losses from diseases can be more than $50 \%$ [9]. Due to the high aggressiveness and virulence of pathogens, the harmfulness of diseases is constantly growing. Also, one of the reasons for the decline in potato yields is the widespread occurrence of pests. Losses from damage that they cause in the process of vital activity can exceed $40 \%$ [10]. In addition, the quality of commercial yield deteriorates and the storability of tubers decreases.

The constant use of chemical pesticides contributes to the development of resistance in both pests and pathogens of potato diseases [11]. In this regard, there is a need for the development of new, improvement of registered pesticides, or the use of biological products. The transition to integrated or biological protection will not only reduce the cost of potato production, overcome the resistance of harmful organisms, but also reduce the toxic load on the environment [5, 12-15].

Due to, the purpose of the work was to assess the effectiveness of biological and chemical systems for protecting potatoes from harmful organisms in the central zone of the Krasnodar region.

\section{Materials and methods}

The studies were carried out in 2020 in the Kalininsky District of the Krasnodar region and the Federal Research Center of Biological Plant Protection. The object of research was potato of the Arrow variety. We studied biological and chemical protection systems (Table 1).

Table 1. Experimental design

\begin{tabular}{|c|c|c|c|c|}
\hline Drugs & Active material & $\begin{array}{l}\text { Consumption } \\
\text { rate }\end{array}$ & $\begin{array}{l}\text { Multiplicity } \\
\text { of } \\
\text { treatments }\end{array}$ & $\begin{array}{l}\text { Method of } \\
\text { application }\end{array}$ \\
\hline \multicolumn{5}{|c|}{ Biological protection system } \\
\hline $\begin{array}{l}\text { Control } \\
\text { (without } \\
\text { treatments) }\end{array}$ & - & - & - & - \\
\hline Geostim, Liq & $\begin{array}{c}\text { Trichoderma viride, } \\
\text { Azomonas agilis, } \\
\text { Azotobacter } \\
\text { chrooccocum }\end{array}$ & $2.0 \mathrm{l} / \mathrm{ha}$ & 1 & Soil spraying \\
\hline BSka-3, Liq & $\begin{array}{c}\text { Trichoderma viride, } \\
\text { Pseudomonas } \\
\text { koreensis, Bacillus } \\
\text { subtilis, } \\
\text { Bradyrhizobium } \\
\text { japonicum } \\
\end{array}$ & $4.0 \mathrm{l} / \mathrm{t}$ & 1 & $\begin{array}{c}\text { Soaking } \\
\text { tubers before } \\
\text { planting }\end{array}$ \\
\hline $\begin{array}{l}\text { BFTIM KS-2, } \\
\text { Liq }\end{array}$ & $\begin{array}{c}\text { Bacillus } \\
\text { amyloliquefaciens }\end{array}$ & $3.0 \mathrm{l} / \mathrm{ha}$ & 2 & $\begin{array}{l}\text { Spraying } \\
\text { during the } \\
\text { growing } \\
\text { season }\end{array}$ \\
\hline Insetim, Liq & $\begin{array}{c}\text { Bacillus } \\
\text { thuringiensis }\end{array}$ & $41 / t$ & 1 & $\begin{array}{l}\text { Spraying } \\
\text { during the } \\
\text { growing } \\
\text { season }\end{array}$ \\
\hline
\end{tabular}




\begin{tabular}{|l|c|c|c|c|}
\hline \multicolumn{5}{|c|}{ Chemical protection system } \\
\hline $\begin{array}{l}\text { Control } \\
\text { (without } \\
\text { treatments) }\end{array}$ & - & - & - & - \\
\hline $\begin{array}{l}\text { Selest TOP, } \\
\text { SC }\end{array}$ & $\begin{array}{c}262.5 \mathrm{~g} / \mathrm{l} \\
\text { thiamethoxam }+ \\
25 \mathrm{~g} / \mathrm{l} \text { difenoconazole } \\
+25 \mathrm{~g} / \mathrm{l} \mathrm{fludioxonil}\end{array}$ & $0.4 \mathrm{l} / \mathrm{t}$ & 1 & $\begin{array}{c}\text { Soaking } \\
\text { tubers before } \\
\text { planting }\end{array}$ \\
\hline $\begin{array}{l}\text { Ridomil Gold } \\
\text { MC, WDG }\end{array}$ & $\begin{array}{c}640 \mathrm{~g} / \mathrm{kg} \text { mancozeb }+ \\
40 \mathrm{~g} / \mathrm{kg} \text { mefenoxam }\end{array}$ & $2.5 \mathrm{~kg} / \mathrm{ha}$ & 1 & $\begin{array}{c}\text { Spraying } \\
\text { during the } \\
\text { growing } \\
\text { season }\end{array}$ \\
\hline Tanos, WDG & $\begin{array}{c}250 \mathrm{~g} / \mathrm{l} \mathrm{famoxadone} \\
+250 \mathrm{~g} / \mathrm{l} \text { cymoxanil }\end{array}$ & $0.6 \mathrm{~kg} / \mathrm{ha}$ & 1 & $\begin{array}{c}\text { Spraying } \\
\text { during the } \\
\text { growing } \\
\text { season }\end{array}$ \\
\hline
\end{tabular}

The area of experimental plots is $100 \mathrm{~m}^{2}$, the area of registration plots is $50 \mathrm{~m}^{2}$. The experiment was carried out in three replicates. The potato planting scheme is two-line. The distance between the lines is $40 \mathrm{~cm}$, in a row $-25 \mathrm{~cm}$, row spacing $-90 \mathrm{~cm}$. The preceding crop was garlic. The following agrotechnical measures were carried out on the plots: peeling to a depth of $7 \mathrm{~cm}$, under-winter ploughing by $30 \mathrm{~cm}$ and cutting of ridges of $6 \mathrm{~cm}$. During the growing season of the crop, manual weeding of weeds was carried out. Before planting potatoes and after harvesting them, a mycological analysis of the soil on the plots was carried out using a biological system of potato protection. Before planting, an analysis of the potato planting material for the presence of harmful objects was carried out. During the growing season of the crop, counts for the presence of diseases and pests were carried out every 10 days, starting from the phase of full seedling (plant height $15-20 \mathrm{~cm}$ ).

\section{Results and discussion}

According to the results of the primary mycological analysis of the soil (before the application of the biological protection system), pathogenic micromycetes of the genera Fusarium and Alternaria were found in the soil, which cause Fusarium blight and Alternaria blight on potatoes, respectively. Fungi of the genera Penicillium, Aspergillus and Trichoderma belong to the suppressive group, their presence in a ratio of 1:1:3 indicates the ability of the soil to resist pathogenic microorganisms. However, in the initial analysis, their ratio was 10:25:1, which indicates a disturbance in the soil balance and, accordingly, low soil suppression.

After the application of the biological potato protection system, a change in the mycological composition of the soil biota was observed. The repeated analysis of the soil did not reveal any fungi of the genus Alternaria however, there was a slight increase in the number of Fusarium sp.

The optimal ratio of fungi of the genus Penicillium, Aspergillus and Trichoderma was not achieved, but a positive trend was observed: the amount of Penicillium sp. decreased to 0.10 thousand pieces/g of soil, Aspergillus sp. up to 0.45 thousand pieces/g of soil and increased the content of Trichoderma sp. up to 0.10 thousand pieces/g of soil, their ratio became 1:4.5:1 (Fig. 1). 


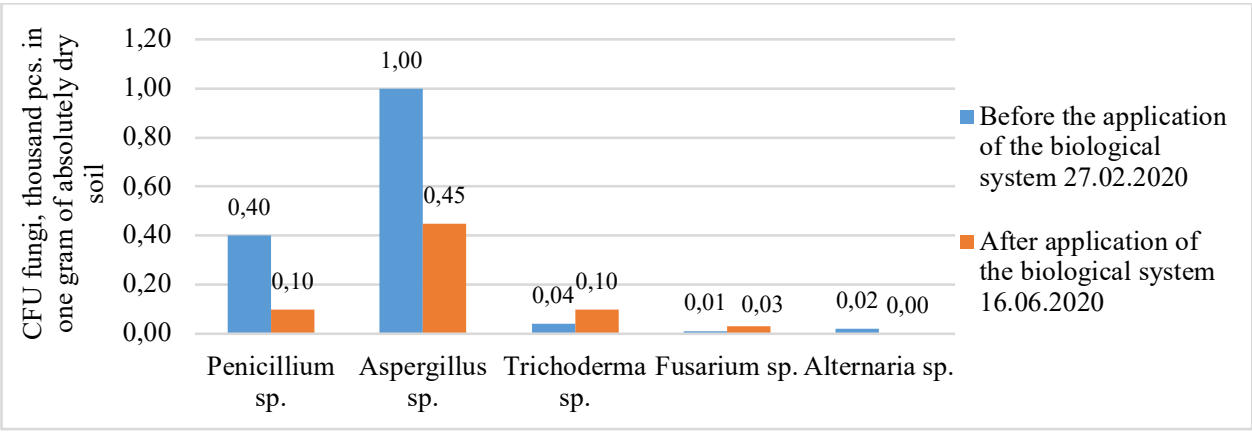

Fig. 1 Results of mycological soil analysis

After the application of the system of chemical protection of potatoes, a decrease in the number of fungi, both pathogenic and suppressive, was noted. In general, with the continued use of the biological potato protection system, a complete restoration of the soil balance of microorganisms is possible.

Preventive spraying (biological protection system) of young potato plants with biological fungicide BFTIM-KS2, Liq. was held on May 11, 2020. On the same day, for preventive purposes, treatment with the fungicide Ridomil Gold MC, WDG was carried out. Retreatment with fungicides was carried out 10 days after the first $(05 / 21 / 2020)$. The drug BFTIM-KS 2 in the variant with biological protection and the fungicide Tanos, WDG in the variant with chemical protection were used. Biometric parameters were measured 10 days after the last fungicide treatment (Fig. 2).

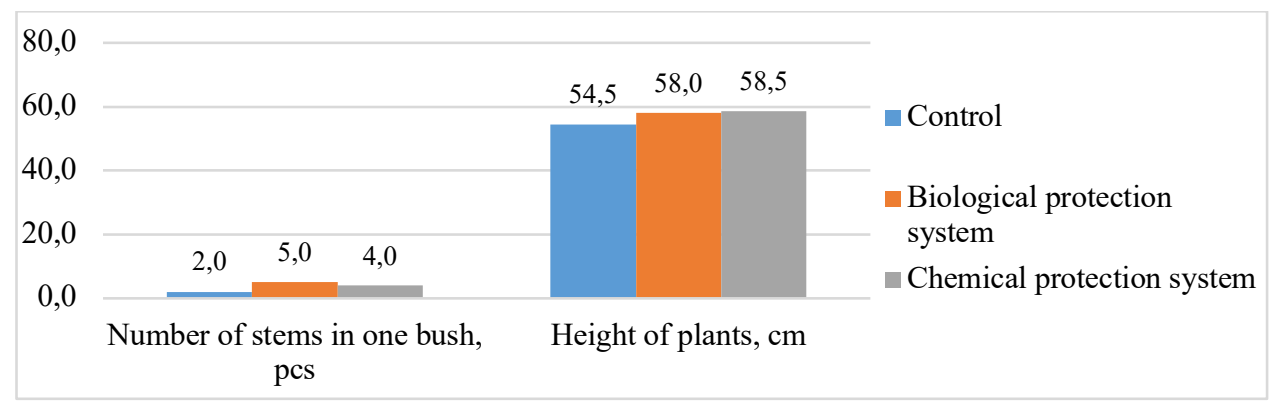

Fig. 2 Biometric indicators of potatoes of Arrow variety, Krasnodar region, 2020

It was noted that the use of a biological protection system stimulated the active growth of the biomass of potato plants. The number of stems was more than 2 times more than in the control variant of the experiment, and higher by $25.0 \%$ compared to the variant of the experiment with a chemical protection system. The height of plants in the variants of the experiment with biological and chemical protection systems differed insignificantly, the difference with the control was $6.4-7.3 \%$.

Also, when carrying out phytosanitary monitoring of plants in all experimental plots, a small number of Colorado potato beetle larvae were noted and treatment was carried out with Insetim, Liq in the variant of the experiment with a biological protection system. Since the number of larvae did not exceed economic injury level, the treatment with a chemical insecticide was not carried out.

When harvesting potatoes, the effect of protection systems on its structure, yield and quality indicators (starch, vitamin $\mathrm{C}$ and nitrate nitrogen content) was assessed.

When assessing the structure of the yield, it was noted that the total number of potato tubers from one bush in the variant with a biological protection system is $40 \%$ more than 
in other variants of the experiment. The mass of tubers from one bush was $12.4-61.7 \%$ higher compared to the control and the variant of the experiment with chemical protection. Separation into fractions showed that in the control variant, tubers of the small fraction predominated, in the variants of biological and chemical protection feeding fraction. However, the variant with the use of biological preparations distinguished itself by a slightly larger mass and quantity of ware potatoes.

One of the main indicators of the effectiveness of the protection system was the yield (Fig. 3).

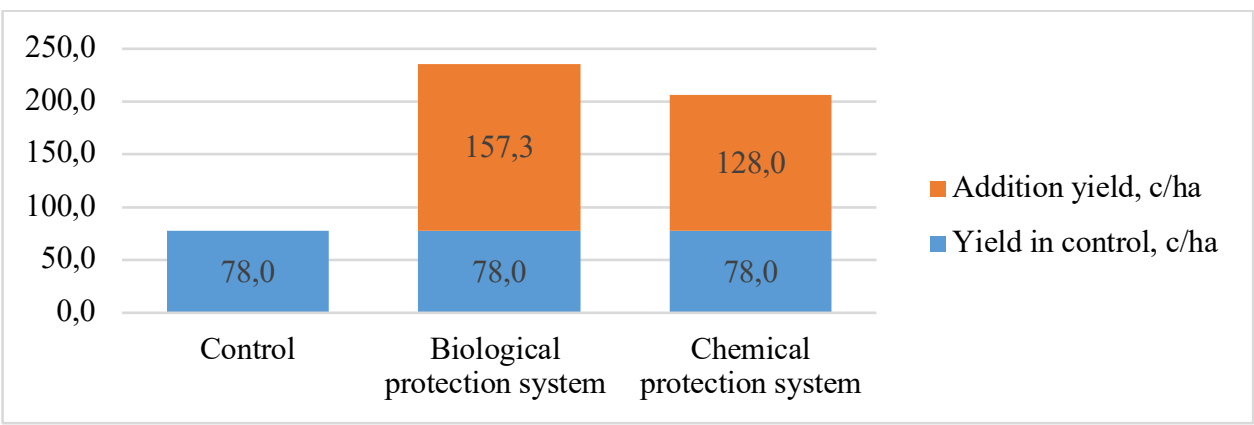

Fig. 3 Yield of potatoes of Arrow variety

When taking into account the yield of potatoes, a significant difference between the control and both protection systems was noted, the yield increase was $157.3 \mathrm{c} / \mathrm{ha}(50.4 \%)$ and $128 \mathrm{c} / \mathrm{ha}(39 \%)$ and for biological and chemical systems, respectively. There was also a significant difference $(22.8 \%)$ between chemical and biological protection systems in favor of biological protection

The quality of potatoes is determined by the content of starch, nitrates and vitamin $\mathrm{C}$ in the tubers (Table 2).

Table 2. Qualitative indicators of the potatoes of Arrow variety

\begin{tabular}{|l|c|c|c|}
\hline Experience option & $\begin{array}{c}\text { Nitrate nitrogen, } \\
\mathrm{mg} / \mathrm{kg}\end{array}$ & $\begin{array}{c}\text { Vitamin C content, } \\
\mathrm{mg} / 100 \mathrm{~g} \text { raw material }\end{array}$ & Starch content, \% \\
\hline Control & 118 & 4.4 & 20.8 \\
\hline $\begin{array}{l}\text { Biological protection } \\
\text { system }\end{array}$ & 138 & 9.3 & 21.3 \\
\hline $\begin{array}{l}\text { Chemical protection } \\
\text { system }\end{array}$ & 187 & 7.9 & 21.2 \\
\hline
\end{tabular}

The maximum permissible content of nitrates in potatoes should not exceed $250 \mathrm{mg} / \mathrm{kg}$. According to this, in all variants the amount of nitrates was within the normal range, however, the highest $(187 \mathrm{mg} / \mathrm{kg})$ was in the variant with the chemical protection system, and the lowest $(118 \mathrm{mg} / \mathrm{kg})$ - in the control. In terms of the content of vitamin C, the variant with the use of biological protection distinguished itself $(9.3 \mathrm{mg} / 100 \mathrm{~g}$ of raw material $)$. In the control variant, the content of vitamin $\mathrm{C}$ was significantly lower than in both protection variants, and amounted to $4.4 \mathrm{mg} / 100 \mathrm{~g}$ of crude substance. In terms of starch content, all variants were at the same level. Its amount varied from $20.8 \%$ to $21.3 \%$. 


\section{Conclusion}

It was determined that the use of biological products partially balanced soil microorganisms, and an increase in the content of Trichoderma sp was noted. The use of biological drugs also had a positive effect on the increase in biometric indicators of potato plants, structural indicators of yield, crop productivity, quality of potato tubers.

Acknowledgments. The research was carried out in accordance with the State Assignment of the Ministry of Science and Higher Education of the Russian Federation within the framework of research on the topic No 0686-2019-0008.

\section{References}

1. P.R. Birch, G. Bryan, B. Fenton, E.M. Gilroy, I. Hein, J.T. Jones, A. Prashar, M.A. Taylor, L. Torrance, I.K. Toth, Food Secur., 4, 477-508 (2012) https://doi.org/10.1007/s12571-012-0220-1

2. S. Diallo, A. Crépin, C. Barbey, N. Orange, J.F. Burini, X. Latour, FEMS Microb. Ecol., 75(3), 351-364 (2011) https://doi.org/10.1111/j.1574-6941.2010.01023.X

3. T.S. George, M.A. Taylor, I.C. Dodd, P.J. White, Potato Res., 60(3), 239-268 (2017) https://doi.org/10.1007/s11540-018-9366-3

4. P. Kromann, T. Miethbauer, O. Ortiz, G.A. Forbes, In: D. Pimentel, R. Peshin (eds) Integrated Pest Management, 245-268 (Springer, Dordrecht, 2014) https://doi.org/10.1007/978-94-007-7796-5 10

5. M. Kołodziejczyk, Acta Agrophys., 25(1), 59-71 https://doi.org/10.31545/aagr0005

6. M. Leonel, E.L. Do Carmo, A.M. Fernandes, R.P. Soratto, J.A.M. Ebúrneo, É.L. Garcia, T.P.R. Dos Santos, J. Food Sci. Technol. 54(8), 2372-2378 (2017) https://doi.org/10.1007/s13197-017-2677-6

7. M. Naumann, M. Koch, H. Thiel, A. Gransee, E. Pawelzik, Potato Res., 63, 121-137 (2020) https://doi.org/10.1007/s11540-019-09430-3

8. S.K. Shakir, S. Irfan, B. Akhtar, S. ur Rehman, M.K. Daud, N. Taimur, A. Azizullah, Ecotoxicology, 27(7), 919-935 (2018) https://doi.org/10.1007/s10646-018-1916-6

9. I.A. Denisenkov, Ach. Sci. Technol. AIC, 32(3), 76-78 (2018) https://doi.org/10.24411/0235-2451-2018-10315

10. S. Sharma, R. Kooner, R. Arora, In: R. Arora, S. Sandhu (eds) Breeding Insect Resistant Crop for Sustainable Agriculture, 45-66 (Springer, Singapore, 2017) https://doi.org/10.1007/978-981-10-6056-4_2

11. J.S. Okonya, J. Kroschel, BioMed Res. Int., 2015, 759049 (2015) https://doi.org/10.1155/2015/759049

12. H.F. Liu, X.J. Xue, Y. Yu, M-M. Xu, Ch-Ch. Lu, X-L. Meng, B-G. Zhang, X-H. Ding, Zh-H. Chu, Mol. Plant Pathol., 21(5), 636-651 (2020) https://doi.org/10.1111/mpp.12919

13. B. Cwalina-Ambroziak, M.M. Damszel, M. Glosek-Sobieraj, J. Plant Prot. Res., 55(4), 389-395 (2015) https://doi.org/10.1515/jppr-2015-0052

14. L.P. Plekhanova, S.A. Buldakov, Int. Res. J., 9(87), 28-33 (2019) https://doi.org/10.23670/IRJ.2019.87.9.031

15. S.N. Nekoval, A.V. Belyaeva, A.E. Sadovaya, I.S. Fedoryanskaya, Ach. Sci. Technol. AIC, 34(11), 54-58 (2020) http://doi.org/10.24411/0235-2451-2020-11107 